\title{
Preface: evolving rotifers, evolving science
}

\section{Proceedings of the XIV International Rotifer Symposium}

\author{
Miloslav Devetter • Diego Fontaneto - Christian D. Jersabek - David B. Mark Welch • \\ Linda May • Elizabeth J. Walsh
}

Published online: 31 May 2017

(C) Springer International Publishing Switzerland 2017

\section{The 14th International Rotifer Symposium}

The International Rotifer Symposium held in České Budějovice, Czech Republic, from August 30th to September 4th 2015 was the 14th meeting of the rotifer family. These Symposia are a series of informal gatherings of researchers interested in rotifers. Participants usually include researchers who devote most, if not

This volume is dedicated to the memory of Jim Green, Charles E. King, and Lyudmila A. Kutikova, and to the renowned rotiferologists Emanuel Bartoš, Josef Donner, and Vladimír Sládeček, who lived and worked in historically Czech lands.

Guest editors: M. Devetter, D. Fontaneto, C. D. Jersabek, D. B. Mark Welch, L. May \& E. J. Walsh / Evolving rotifers, evolving science

M. Devetter $(\bowtie)$

Biology Centre, Institute of Soil Biology, The Czech

Academy of Sciences, Na Sádkách 7,

37005 České Budějovice, Czech Republic

e-mail: devetter@upb.cas.cz

M. Devetter

University of South Bohemia, Branišovská 31,

37005 České Budějovice, Czech Republic

D. Fontaneto

National Research Council of Italy, Institute of Ecosystem

Study, Largo Tonolli 50, 28922 Verbania Pallanza, Italy

C. D. Jersabek

Department of Organismal Biology, University of

Salzburg, 5020 Salzburg, Austria all, of their time to aspects of rotifer biology, ecology, and systematics, practitioners who encounter rotifers in their work, and researchers from disparate fields who find rotifers to be interesting model systems to address their research questions. In 2015, attendees included 124 participants from 28 countries (Fig. 1), with highest representation from Mexico, USA, and China.

The 14th symposium continued the informal atmosphere of previous meetings, and the papers assembled here represent part of the research findings that were presented and discussed, or ideas that were developed during the meeting. The papers cover a wide array of research questions that are addressed using rotifers as the focal species. The most well-known model system among rotifers is the complex of cryptic and pseudo-

D. B. Mark Welch

Marine Biological Laboratory, Josephine Bay Paul Center for Comparative Molecular Biology and Evolution, Woods Hole, MA, USA

L. May

Centre for Ecology \& Hydrology, Bush Estate, Penicuik, Midlothian EH26 0QB, Scotland, UK

E. J. Walsh

Department of Biological Sciences, University of Texas at El Paso, El Paso, TX, USA 

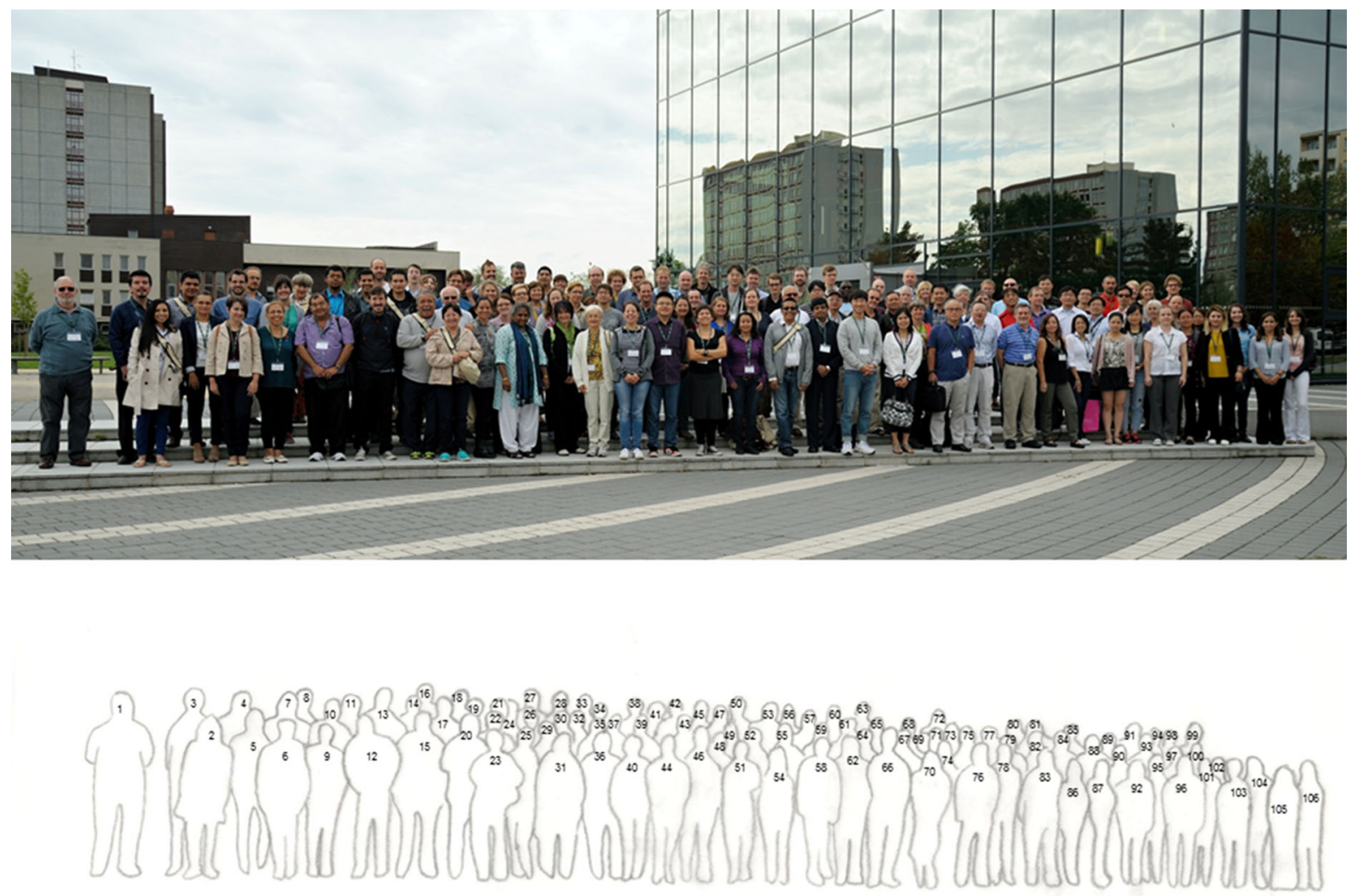

Fig. 1 Group photo of the attendees of the 14th International Rotifer Symposium held in České Budějovice, Czech Republic, from August 30th to September 4th 2015. 1: Giulio Melone, 2: Alma Rosa Núñez Ortiz, 3: Gerardo García García, 4: Uriel Arreguin Rebolledo, 5: Wioleta Kocerba-Soroka, 6: Georgia Stamou, 7: Lluís Franch Gras, 8: Miloslav Devetter, 9: Evangelia Michaloudi, 10: Eva Tarazona Castelblanque, 11: Claudia Ricci, 12: Roberto Rico-Martínez, 13: Marco Antonio Jiménez Santos, 14: Daniel Robles Vargas, 15: Eduardo M. García-Roger, 16: Karel Janko, 17: Manuel Eduardo Muñoz Colmenarez, 18: Christopher G Wilson, 19: Nataliia Iakovenko, 20: José Luis Gama-Flores, 21: Adam Cieplinsky, 22: Ivo Přikryl, 23: María Elena Huidobro-Salas, 24: unidentified, 25: Martha Angélica Gutiérrez-Aguirre, 26: Naomi Zweerus, 27: Matthieu Terwagne, 28: Bernard Hallet, 29: Anna Basińska, 30: Jolanta Ejsmont-Karabin, 31: Nandini Sarma, 32: Maria Rosa Miracle, 33: Adrián Cervantes Martínez, 34: Karine Van Doninck, 35: Julie Blommaert, 36: Maria Špoljar, 37: Natalia Kuczynska-Kippen, 38: Luc Brendonck, 39: Claus-Peter Stelzer, 40: Elizabeth Wurdak, 41: Diego Fontaneto, 42: Holger Herlyn, 43: Denis Roze, 44: Simone Riß, 45: Daniel Vařecha,

cryptic species that goes under the name of $\mathrm{Bra}$ chionus plicatilis Müller. This species complex is frequently used in aquaculture, as food for fish, and in ecological and evolutionary studies. As a result, several papers deal with members of this species complex, including the ecological and evolutionary
46: Qing Wang, 47: Stefan Sommer, 48: Adriana Aránguiz Acuña, 49: Tvrtko Drazina, 50: Steven Declerck, 51: Raquel Ortells, 52: Sevil Erdogan, 53: Raehyuk Jeong, 54: Teresa Ramírez-Pérez, 55: Evelien Rozema, 56: Dzmitry Lukashanets, 57: Boris Hespeels, 58: Mario Alfredo Fernandez Araiza, 59: Alois Herzig, 60: David Mark Welch, 61: Shohei Kamizono, 62: S.S.S. Sarma, 63: Mateusz Danilczyk, 64: Ramesh Gulati, 65: Erick Ochieng Ogello, 66: Jeonghoon Han, 67: Christian D. Jersabek, 68: Jakub Baczyński, 69: Yufeng Yang, 70: Helen Marcial, 71: Robert L. Wallace, 72: Guntram Weithoff, 73: Elizabeth Walsh, 74: Ulrike Obertegger, 75: Xu-Wang Yin, 76: Jae-Seong Lee, 77: Esther Lubzens, 78: Jiaxin Yang, 79: Manuel Serra, 80: Michal Šorf, 81: Michael Gotesman, 82: Atsushi Hagiwara, 83: Terry Snell, 84: Taavi Virro, 85: Wei Zhang, 86: María José Carmona Navarro, 87: Celia Joaquim-Justo, 88: Xinli Wen, 89: Libin Zhou, 90: Shuang-huai Cheng, 91: Marc Llirós Dupré, 92: Huan Zhang, 93: Xianling Xiang, 94: unidentified, 95: Yali Ge, 96: Külli Lokko, 97: Linda May, 98: Jessica Beyer, 99: unidentified, 100: Shuyu Gu, 101: Hong Geng, 102: Cuijuan Niu, 103: unidentified, 104: Elizabeth Preza, 105: Maite Martin, 106: Rachel Kelsey Johnston

consequences of its taxonomic, systematic, and nomenclatural intricacies (Gabaldón et al., 2017; Michaloudi et al., 2017; Mills et al., 2017; Riss et al., 2017), dormancy (Montero-Pau et al., 2017), population dynamics (Kamizono et al., 2017), and culture methods (Ogello et al., 2017). 

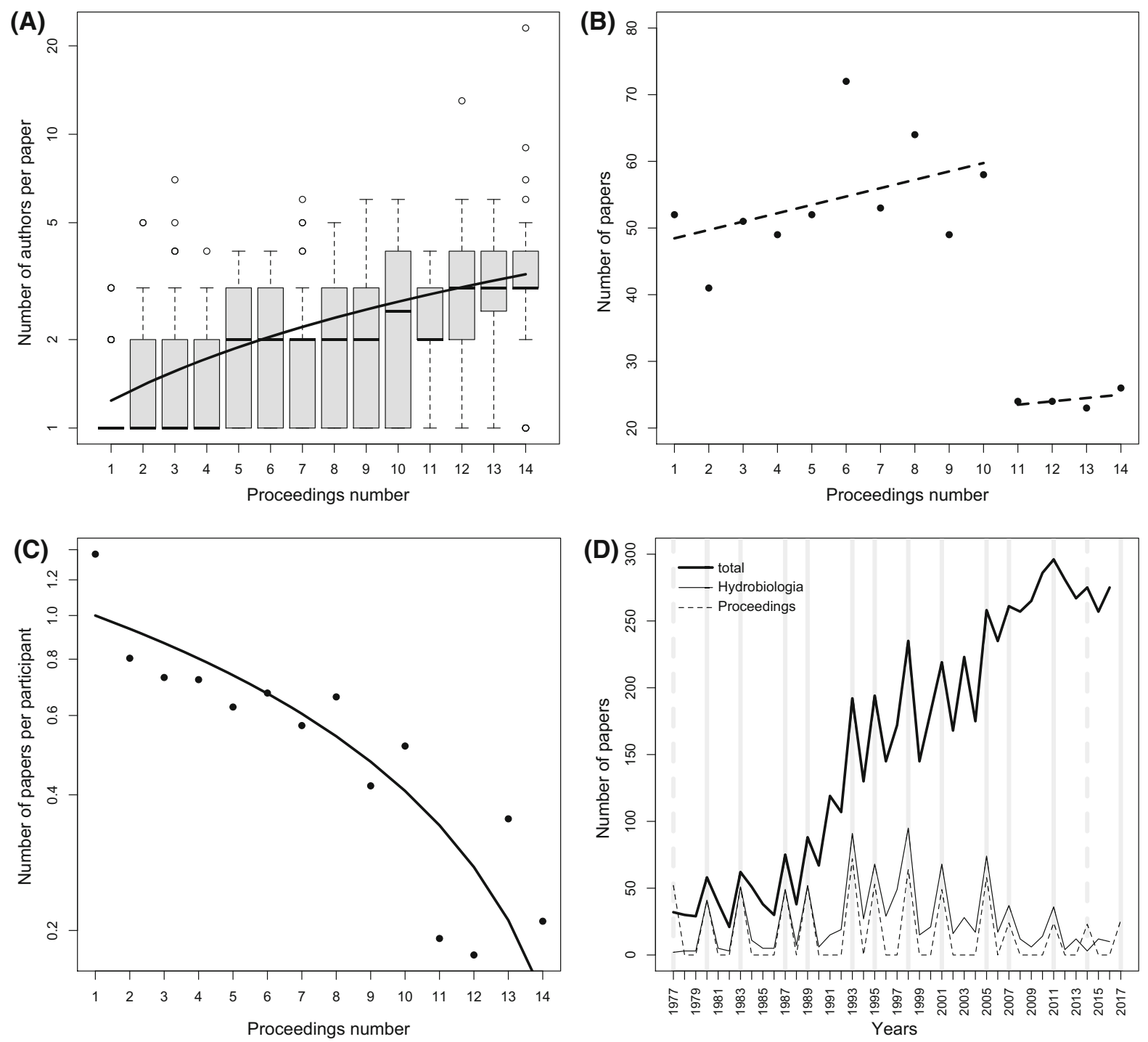

Fig. 2 Publication trends from the Proceedings of the Fourteen International Rotifer Symposia, 1977-2017. A Distribution of the number of authors per paper, on a logarithmic scale. The trend line represents the results of a linear regression model using logarithmic transformation of the number of authors as the response variable and proceeding number as the explanatory variable $(t=11.3, P<0.0001)$. B Number of papers in each of the proceedings. The two dashed lines represent the nonsignificant trends for the two periods from volume 1 to 10 $(t=1.4, P=0.206)$ and volume 11 to $14(t=0.8, P=0.487)$. Although no trend is shown in either period, the number of papers per volume in the first period is significantly higher than

Another model rotifer species that is now providing a useful comparison with B. plicatilis is Brachionus calyciflorus Pallas. Two papers in this volume cover its population dynamics (Sommer et al., 2017; Zweerus et al., 2017) and a third one a rationale for

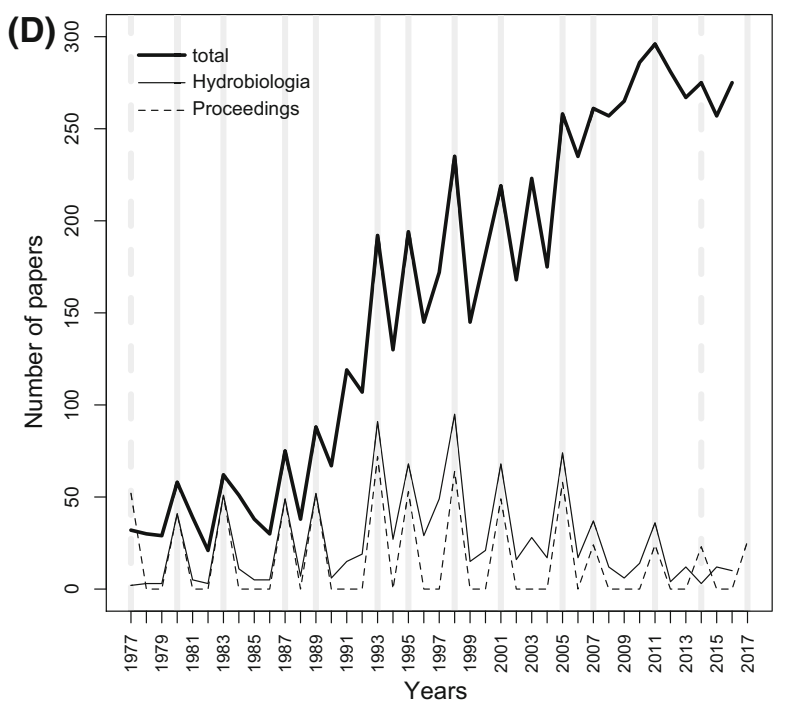

that in the second (ANOVA: $F_{1,12}=44.8, \quad P<0.0001$ ). C Number of papers per participant in each of the proceedings, on a logarithmic scale. The trend line represents the results of a linear regression model using logarithmic transformation of the number of papers per participant as the response variable and proceeding number as the explanatory variable $(t=-6.7$, $P<0.0001)$. D Number of published papers on rotifers from 1977 to 2016, only in the proceedings, only in Hydrobiologia, and in total across all journals. The grey vertical lines represent the years of the proceedings, published as special issues either in Hydrobiologia (continuous lines) or in other journals (dashed lines)

its use in eco-evolutionary studies, together with other species (Declerck \& Papakostas, 2017). There are examples of other species being used as model species to solve taxonomic problems (Cieplinski et al., 2017; Wurdak, 2017), to explore the factors that affect 

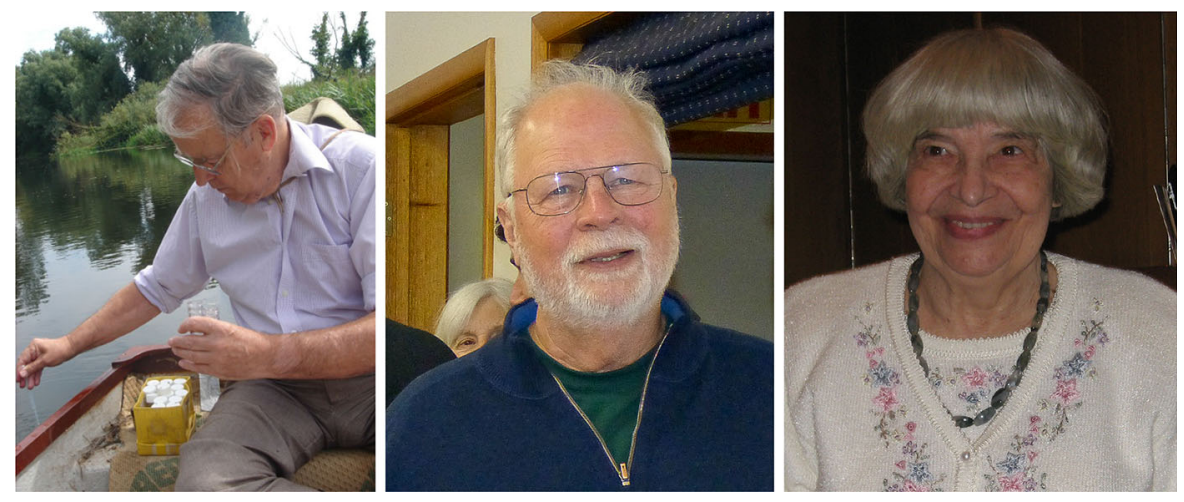

Fig. 3 Jim Green (1928-2016), Charles E. King (1934-2016), and Lyudmila A. Kutikova (1928-2015)

population dynamics and adaptation (Santos-Medrano et al., 2017; Sarma et al., 2017; Walczynska et al. 2017), and to provide insight into aspects of dormancy in monogonont (Brendonck et al., 2017; García-Roger et al. 2017; Gilbert, 2017; Snell, 2017; Stelzer, 2017; Walsh et al., 2017) and bdelloid rotifers (Ricci, 2017). In addition to studies targeting individual species or groups of species, other approaches presented here address issues of community ecology and correlates of biological diversity (Lokko et al., 2017; Meyer et al., 2017; Stamou et al., 2017).

\section{Scientometric trends in rotifer publications}

The topics covered by the Rotifer Symposia have remained similar over time, but some interesting scientometric trends can be clearly seen when comparing the proceedings from the first meeting published in 1977 to the current one published 40 years later, trends that were already beginning to emerge in the previous meeting (Sharma et al., 2014). The number of authors associated with each paper has increased consistently over time, starting at 1.3 in 1977 and reaching 4.2 by 2017 (Fig. 2A). The current proceedings volume includes the paper with the highest number of authors ever recorded for any paper published from the Symposia. This paper (Mills et al., 2017), with 23 authors from 20 institutions spread across 13 countries and 4 continents, represents both the global reach and collaborative spirit of these Symposia.

Another interesting trend, highlighted in the previous meeting (Sharma et al., 2014), is the reduction in the overall number of papers published in each proceedings volume (Fig. 2B). There is a clear separation between volumes 1 (1977) to 10 (2005), with 41-72 papers each, and volumes 11 (2007) to 14 (2017), with 23-26 papers each. These differences could be due to changes in editorial processes but, when comparing the number of papers to the number of participants at each Symposium, the two groups merge and a generally decreasing trend appears (Fig. 2C). However, since 1990, the total number of papers published on rotifers outside of the symposia proceedings has increased dramatically (Fig. 2D), demonstrating that rotifer scientists have widened the horizon of their publishing activities and suggesting increased recognition of the relevance of rotifers in a broader biological context. This trend appears to be in common with other taxon-based symposia: participants publish less in the resulting proceedings, and many meetings simply do not publish proceedings anymore, because many papers are often directed at higher impact journals (Koen Martens, Editor in Chief of Hydrobiologia, personal communication).

The 638 papers published across all of the 14 proceedings illustrate well how rotifers adapt to their environment in terms of their morphology, population dynamics, community ecology, and evolution. At the same time, the clear scientometric trends show that rotifer scientists have also had to adapt to changing scientific pressures by changing the way they publish and by involving a larger number of collaborators.

\section{In memoriam}

A sad outcome of evolution is the contingency of our lives as researchers and as people, and here we 
remember the recently deceased Jim Green (1928-2016), Charles E. King (1934-2016), and Lyudmila A. Kutikova (1928-2015) (Fig. 3), who each contributed so much to the study of rotifers and to the community of rotiferologists throughout their long and productive careers.

\section{References}

Brendonck, L., T. Pinceel \& R. Ortells, 2017. Dormancy and dispersal as mediators of zooplankton population and community dynamics along a hydrological disturbance gradient in inland temporary pools. Hydrobiologia. doi:10. 1007/s10750-016-3006-1.

Cieplinski, A., T. Weisse \& U. Obertegger, 2017. High diversity in Keratella cochlearis (Rotifera, Monogononta): morphological and genetic evidence. Hydrobiologia. doi:10. 1007/s10750-016-2781-z.

Declerck, S. A. \& S. Papakostas, 2017. Monogonont rotifers as model systems for the study of micro-evolutionary adaptation and its eco-evolutionary implications. Hydrobiologia. doi:10.1007/s10750-016-2782-y.

Gabaldón, C., D. Fontaneto, M. J. Carmona, J. Montero-Pau \& M. Serra, 2017. Ecological differentiation in cryptic rotifer species: what we can learn from the Brachionus plicatilis complex. Hydrobiologia. doi:10.1007/s10750-016-2723-9.

García-Roger, E. M., M. J. Carmona \& M. Serra, 2017. Modes, mechanisms and evidence of bet hedging in rotifer diapause traits. Hydrobiologia. doi:10.1007/s10750-0162869-5.

Gilbert, J. J., 2017. Resting-egg hatching and early population development in rotifers: a review and a hypothesis for differences between shallow and deep waters. Hydrobiologia. doi:10.1007/s10750-016-2867-7.

Kamizono, S., E. O. Ogello, Y. Sakakura \& A. Hagiwara, 2017. Effect of starvation and accumulation of generations on mixis induction in offspring of the monogonont rotifer Brachionus manjavacas hatched from resting eggs. Hydrobiologia. doi:10.1007/s10750-016-3078-y.

Lokko, K., T. Virro \& J. Kotta, 2017. Seasonal variability in the structure and functional diversity of psammic rotifer communities: role of environmental parameters. Hydrobiologia. doi:10.1007/s10750-016-2923-3.

Meyer, M. F., S. E. Hampton, T. Ozersky, O. O. Rusanovskaya \& K. H. Woo, 2017. Vulnerability of rotifers and copepod nauplii to predation by Cyclops kolensis (Crustacea, Copepoda) under varying temperatures in Lake Baikal, Siberia. Hydrobiologia. doi:10.1007/s10750-016-3005-2.

Michaloudi, E., S. Mills, S. Papakostas, C. P. Stelzer, A. Triantafyllidis, I. Kappas, K. Vasileiadou, K. Proios \& T. J. Abatzopoulos, 2017. Morphological and taxonomic demarcation of Brachionus asplanchnoidis Charin within the Brachionus plicatilis cryptic species complex (Rotifera, Monogononta). Hydrobiologia. doi:10.1007/ s10750-016-2924-2.
Mills, S., J. A. Alcantara-Rodriguez, J. Ciros-Pérez, A. Gómez, A. Hagiwara, K. Hinson Galindo, C. D. Jersabek, R. Malekzadeh-Viayeh, F. Leasi, J.-S. Lee, D. B. Mark Welch, S. Papakostas, S. Riss, H. Segers, M. Serra, R. Shiel, R. Smolak, T. W. Snell, C. P. Stelzer, C. Q. Tang, R. L. Wallace, D. Fontaneto \& E. J. Walsh, 2017. Fifteen species in one: deciphering the Brachionus plicatilis species complex (Rotifera, Monogononta) through DNA taxonomy. Hydrobiologia. doi:10.1007/s10750-016-2725-7.

Montero-Pau, J., M. Serra \& A. Gómez, 2017. Diapausing egg banks, lake size, and genetic diversity in the rotifer Brachionus plicatilis Müller (Rotifera, Monogononta). Hydrobiologia. doi:10.1007/s10750-016-2833-4.

Ogello, E. O., Y. Sakakura \& A. Hagiwara, 2017. Culturing Brachionus rotundiformis Tschugunoff (Rotifera) using dried foods: application of gamma-aminobutyric acid (GABA). Hydrobiologia. doi:10.1007/s10750-016-3032-z.

Ricci, C., 2017. Bdelloid rotifers: 'sleeping beauties' and 'evolutionary scandals', but not only. Hydrobiologia. doi:10.1007/s10750-016-2919-z.

Riss, S., W. Arthofer, F. M. Steiner, B. C. Schlick-Steiner, M. Pichler, P. Stadler \& C. P. Stelzer, 2017. Do genome size differences within Brachionus asplanchnoidis (Rotifera, Monogononta) cause reproductive barriers among geographic populations? Hydrobiologia. doi:10.1007/s10750016-2872-x.

Santos-Medrano, G. E., D. Robles-Vargas, S. Hernández-Flores \& R. Rico-Martinez, 2017. Life table demography of Asplanchna brightwellii Gosse, 1850 fed with five different prey items. Hydrobiologia. doi:10.1007/s10750-016-3069$\mathrm{z}$.

Sarma, S. S. S., M. A. Jiménez-Santos, S. Nandini \& R. L. Wallace, 2017. Demography of the sessile rotifers, Limnias ceratophylli and Limnias melicerta (Rotifera: Gnesiotrocha), in relation to food (Chlorella vulgaris Beijerinck, 1890) density. Hydrobiologia. doi:10.1007/ s10750-017-3184-5.

Sharma, B. K., H. J. Dumont \& R. L. Wallace, 2014. Rotifer biology: a structural and functional approach-preface. International Review of Hydrobiology 99: 1-2.

Snell, T. W., 2017. Analysis of proteins in conditioned medium that trigger monogonont rotifer mictic reproduction. Hydrobiologia. doi:10.1007/s10750-016-2936-y.

Sommer, S., K. J. van Benthem, D. Fontaneto \& A. Ozgul, 2017. Are generic early-warning signals reliable indicators of population collapse in rotifers? Hydrobiologia. doi:10. 1007/s10750-016-2948-7.

Stamou, G., C. Polyzou, A. Karagianni \& E. Michaloudi, 2017. Taxonomic distinctness indices for discriminating patterns in freshwater rotifer assemblages. Hydrobiologia. doi:10. 1007/s10750-016-2894-4.

Stelzer, C. P., 2017. Extremely short diapause in rotifers and its fitness consequences. Hydrobiologia. doi:10.1007/s10750016-2937-x.

Walczyńska, A., L. Franch-Gras \& M. Serra, 2017. Empirical evidence for fast temperature-dependent body size evolution in rotifers. Hydrobiologia. doi:10.1007/s10750-0173206-3.

Walsh, E. J., L. May \& R. L. Wallace, 2017. A metadata approach to documenting sex in phylum Rotifera: 
diapausing embryos, males, and hatchlings from sediments. Hydrobiologia. doi:10.1007/s10750-016-2712-z.

Wurdak, E., 2017. External morphology of the eggs of Asplanchnopus multiceps (Schrank, 1793) (Rotifera): solving the 150-year-old case of mistaken identity. Hydrobiologia. doi:10.1007/s10750-016-2831-6.
Zweerus, N. L., S. Sommer, D. Fontaneto \& A. Ozgul, 2017. Life-history responses to environmental change revealed by resurrected rotifers from a historically polluted lake. Hydrobiologia. doi:10.1007/s10750-016-3070-6. 